\title{
National mega-projects as an instrument of competitive development of Russian regions
}

\author{
Vladimir Ivanov \\ Moscow Polytechnic University \\ Ryazan Institute (division) \\ The Department of «Economics, management and marketing» \\ Ryazan, Russia \\ ivu.iwanow@yandex.ru
}

\begin{abstract}
This article considers the theory and practice of implementation of two types of national mega-projects essential in modern Russia: event-strategic and infrastructure megaprojects. The author presents his own approach to the general classification of mega-projects, based on the expansion of the approaches of Russian scientists by distinguishing two main types of mega-projects (event-related and infrastructural), different from the existing mega-project classifications by participants, sources of financing, the scope of implementation; and the introduction of a new basis for the classification of mega-projects - by the instruments used for their implementation. The article describes the main problems of implementation of mega-projects. The uniqueness of mega-projects predetermined the risks of their implementation, which are described in the study. The specificity of such type of mega-project as event-strategic state-significant set forth in the article, and its author's definition is presented. The basis of the proposed definition of event-strategic statesignificant mega-projects was the study of criteria, types, risks of mega-projects. The general algorithm and tools for such events, as well as experience in the implementation of event-strategic state-significant mega-projects in the regions of Russia is described in the paper. The immensity of implementation of infrastructure mega-projects has allowed us to give consideration only to some of them. The author substantiates the necessity of distinguishing among the national mega-projects a special type of projects - epoch-making mega-projects - as a condition of Russia's advance in the prism of global competition and the need to ensure sustainable and safe development of regions.
\end{abstract}

Keywords - mega-project, event-strategic state-significant mega-projects, infrastructure mega-projects, epoch-making megaprojects

\section{INTRODUCTION}

In the context of the introduction into Russian practice of the concept of improving the efficiency of public expenditure management through the transition from a model of cost management to a model of results management, the executive authorities are increasingly focusing on global mega-projects aimed at solving various kinds of national and supranational socio-economic problems based on the program-target and service approaches to planning and spending of state and municipal budgets. Modern development of methodology of strategic management of the state, tools of regional development, forms and methods of social partnership of business and government, coupled with the active development of process and technology served as an impetus and prerequisite for the mass emergence of large-scale unique, landmark projects in Russia and the world - mega-projects. Such mega-projects are characterized by a number of new properties, provide new development opportunities for the whole country and its certain territories, and bear new risks, which require special technologies to manage them.

However, "the general culture of design, planning and implementation" of such epoch-making infrastructure megaprojects both in Russia and in the world "is not high yet" [1].

The purpose of the article is to consider the Russian experience in the implementation of state mega-projects from the perspective of their place and role in ensuring sustainable and competitive regional development (of the territories of their implementation).

\section{MAterials AND Methods (Model)}

The open access data on event-strategic state-significant mega-projects conducted in Russia (APEC summit 2012, Worldwide Summer Universiade 2013, the $22^{\text {nd }}$ Olympic Games 2014, etc.) [2]., as well as on major infrastructure projects being implemented (bridge across the Kerch Strait, "Northern Sea Route" project, "Energy super-circle" project, etc.) were the empirical base of the study. The sources of information were the official websites of the Executive authorities of the federal, regional and local levels, including ministries and departments that control and finance the implementation of the mega-projects being considered; commercial and non-commercial participants in the implementation of mega-projects; Rosstat; Bank of Russia, etc.

Contemporary Russian and foreign experience in the implementation of a number of complex territorial megaprojects is presented in the publications of such modern Russian scientists as Batmanova V.V., Zhukov A.N., Mitrofanova I.V. and others.

The research methodology is presented by comparative analysis, synthesis, historical and logical approach to the consideration of mega-projects, tabular and graphical methods of data processing and presentation. 


\section{RESULTS AND DISCUSSION}

Despite the widespread practice of mega-projects in Russia and the world, there is no unified terminology base for their research and description [3].

In most cases, we are talking about mega-objects as large investment projects with specific characteristics, such as: large scale (for the economy of the country in whole or its large sector), economic and social effects, capital intensity, state participation and private partnership, investing through the use of long money, time lag, increased risk [4].

Furthermore, mega-projects involve high levels of income and expenditure with significant asset dynamics; the need to solve the problems of international business; the remoteness of areas where mega-projects are implemented and additional costs for their infrastructure; their great impact on the social and economic spheres of the region and even the country where the mega-project is implemented.

Numerically, the characteristics of the mega-project take the following form: the cost starting from 1 billion US dollars [1]; the total amount of work in man hours: 2 million man hours for the design engineering, 15 million man hours for the construction of facilities; long-term implementation of 5-7 years or more.

A. Classification of mega-projects

Mega-projects can be classified on various criteria, see, e.g., S.V. Kekeleva's approach, with which we agree in many respects, aside from the fact that (refer to Table 1): we distinguish event-related and infrastructure mega-projects; otherwise classify the participants of mega-projects, sources of financing, the scope of implementation of mega-projects; for the possibility of cross-country comparison we consider it necessary to keep records of costs of mega-projects in rubles and foreign currencies (mainly in US dollars); we also introduce another criteria for the classification - by the instruments used to implement the mega-project.

In the course of this approach mega-projects "are now becoming an independent format for developing a strategy for a particular region, district, affecting the speed and quality of transformation of the economic space of both the territory of implementation and contiguous regions" [1]. A number of authors are on the same view, among them: Voloshina A.Y. [5], Inshakov O.V. [6], and others.

Ongoing projects of development of new territories create "new economic framework" (in terminology of Mitrofanova I.V., Tlisov A.B., Zhukov A.N., Shavtikova L.M.) [1] in problem regions of Russia and prerequisites for the dynamic development of Siberia and the Far East. Such mega-projects are comprehensively implemented in the territory of the Lower Angara region, Southern Yakutia, Trans-Baikal, and the Arctic. They account for $62 \%$ of all investments in the YransUral part of Russia.

TABLE I. AUTHOR'S APPROACH TO CRITERION OF CLASSIFICATION OF MEGA-PROJECTS BASED ON CLASSIFICATION OF MEGA-PROJECTS OFFERED BY KEKELEVA S.V.

\begin{tabular}{|c|}
\hline Criteria and mega-projects types \\
\hline By intention \\
\hline $\begin{array}{l}\text { 1) socially focused: achievement of high level and living standards of the society; 2) infrastructural: creating objects of transport, energy, innovation } \\
\text { infrastructure, etc.; 3) natural-resourse: development of geologic reserves; 4) environmental: leveling of environmental damage, resource-saving technologies; } \\
\text { 5) science and technology oriented: exploratory researches, engineering and innovative activity; } 6)^{*} \text { event-related: implementation of the mega-project is } \\
\text { associated to a certain politically important and internationally significant event - the one that has image and political components, that is, it is an event mega- } \\
\text { project of the direction strategically important for the whole country }\end{array}$ \\
\hline By purposes \\
\hline $\begin{array}{l}\text { 1) economically oriented: achievment of economic efficiency; 2) community-focused: achievment of positive social effect; } 3 \text { ) politically oriented: achievment } \\
\text { of positive political effect on the regional (local) level, on the international stage }\end{array}$ \\
\hline By participants* \\
\hline $\begin{array}{l}\text { 1) state (municipality), commercial entity (business), non-profit organizations; 2) domestic, foreign members; 3) investors, recipients; 4) facilitators, co- } \\
\text { organizers, partners, members, spectators }\end{array}$ \\
\hline By duration \\
\hline 1) short-term; 2) medium-term; 3) long-term \\
\hline $\begin{array}{ll} & \text { By volume of financing } \\
\end{array}$ \\
\hline $\begin{array}{l}\text { 1) less than } 100 \text { RUB bn; 2) } 100-500 \text { RUB bn; 3) over } 500 \text { RUB bn. } \\
\text { *limits of funding are double - in rubles and in currency (for international comparison and correlation) }\end{array}$ \\
\hline By pay back period \\
\hline 1) less than 10 years; 2) 10-15 years; 3) over 15 years \\
\hline By sources of financing* \\
\hline $\begin{array}{l}\text { 1) funds of budgetary system (federal, regional, local budgets); 2) means of non-budgetary (sovereign wealth) funds; } 3 \text { ) investors' funds (private, state, foreign, } \\
\text { domestic, big, small - crowdfunding); 4) creditors' funds (private, state, foreign, domestic, big, small - crowdfunding, bank, nonbank credit institutions); 5) } \\
\text { private-public partnership, PPP }\end{array}$ \\
\hline By scope of implementation* \\
\hline 1) national, supranational; 2) macro- and micro-regional, interregional \\
\hline $\begin{array}{ll} & \text { By industrial index }\end{array}$ \\
\hline 1) intra-industry; 2) inter-industry (including clustered) \\
\hline By instruments used $* *$ \\
\hline $\begin{array}{l}\text { 1) private-public partnership; 2) life cycle contract; 3) crowdfunding; 4) crowdsourcing; 5) volunteering; 6) commercialization of tangible and intangible } \\
\text { objects }\end{array}$ \\
\hline
\end{tabular}

a. Note: *- author's approach to or instead of S.V. Kekeleva's approach; ** - author's basis for megaprojects classification. 
B. The main problems of mega-projects implementation: Russia's experience

Based on the experience of implemented mega-projects in Russia and the world, specialists indicate the following main problems of their implementation:

1) risks inherent to mega-projects. As noted by Mitrofanova I.V., Zhukov A.N., Tlisov A.B., Zhukov V.N. and Shavtikova L.M., «the uniqueness of each mega-project affects the occurrence of typical and specific risks, including: macroeconomic, political, geographic, engineering, technical, financial, commercial, organizational and legal, tariff, tax, competence, personnel, corruption (criminal), reputation, etc.» [1] (refer to Fig.1).

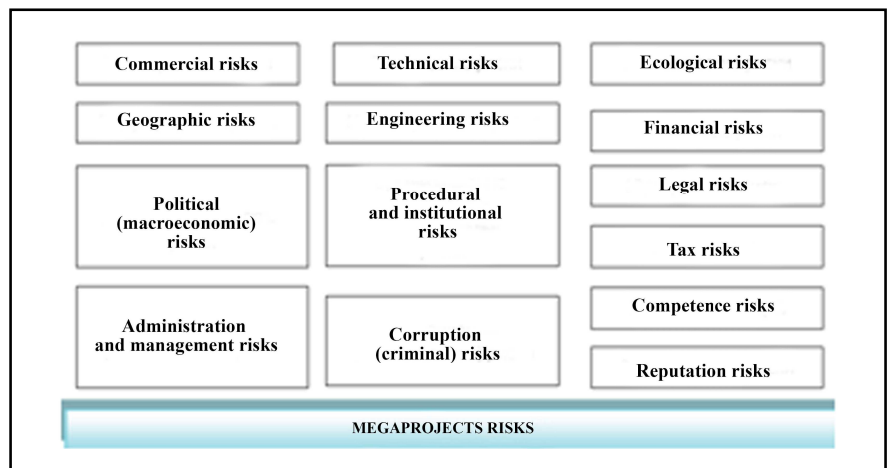

Fig. 1. Megaprojects risks according to approach of Mitrofanova I.V., Zhukov A.N. [drawn up by author after [1].

In addition, all mega-projects are inherently at risk of overspending compared to the originally planned amount (socalled problem of estimation of final cost of the mega-project).

Kekeleva S.V., analyzing foreign experience of financing transport mega-projects, noted significant budget overruns. According to the data announced by her, the final costs for the construction of the Tunnel under the English Channel (England - France, 1994) were 80\% more than planned due to changes in security requirements. Infrastructure (transport) mega-project "The Great belt" (East Denmark - mainland Europe, 1997) cost 54\% more than the planned level due to environmental problems and accidents. The infrastructure

(transport) cross-national mega-project "The Oresund bridge -

tunnel" (Sweden-Denmark, 2000) grew by $26 \%$ due to the "integration of large transport infrastructure into the limited space of the Denmark's capital" [4]. In Russia, there is also an excess of final costs over the planned ones. So, the expenditure of the USSR after 12 years of BAM construction exceeded the planned 4 times [7].

In view of the duration of the mega-project implementation there is often a risk of failing to meet the terms of construction and putting objects into operation by the general contractors/subcontractors. This risk can be minimized by increasing and tightening the criteria for the selection of general contractors, design and survey institutes, suppliers of equipment and materials, inclusion in contracts of bank guarantees for the return of advance payments, increasing penalties for failure to meet deadlines and delivery of equipment, preliminary accreditation of manufacturers, contractors, as well as through continuous monitoring of performance of contractual obligations and the use of its own technical supervision service for the quality of construction.

2) the projected demand for the results of the mega-project may be lower than the real demand. It is necessary for megaprojects to predict the demand for their results, which should become the basis for the "socio-ecological and economic evaluation of infrastructure mega-projects" [4]. Kekeleva S.V. by the example of three foreign infrastructure (transport) mega-projects (the Tunnel under the English Channel, The Great Belt, The Oresund bridge-tunnel) has highlighted that under the obvious cost overrun, the forecast indicators for passenger traffic flow in the first years of the projects operation were not achieved.

3) the environmental component of the mega-project is often underestimated, which subsequently affects the growth of financial and time costs to eliminate or mitigate the consequences of the intervention of the project results or processes in the natural and geological sphere of the territories. As noted by Kekeleva S.V., "quite often, the environmental factor is underestimated to the full extent, and the estimated costs of preventive measures to exclude or eliminate destructive anthropogenic interference are significantly underestimated, which further distorts estimated data and leads to overspending of the planned funds" [4].

\section{Event-strategic state-significant mega-projects of Russia}

Development of a positive image of Russia on the world arenas, starting with the sphere of sport and culture and ending with the sphere of international financial and economic cooperation correspond to strategic political interests of the Russian Federation [8]. One of the forms of increasing the international influence and image of Russia was the holding of various specialized international events (mega-events in the terminology of Baumann R. and Matheson V. [9]), for the organization of which event-strategic state-significant megaprojects are used [3].

Event-strategic state-significant mega-projects (further ESP) shall mean the major sports-building, politically-eventful integrated projects the implementation of which is dedicated to carrying out of large state-important and politically significant sporting, economic, political and other inter-country and intracountry activities financed mainly by the Federal budget [3] (refer to fig. 2).

Among the ESPs of modern Russia, we can highlight the organization and conduct of the following events: APEC summit in Vladivostok in 2012; the XXVII world summer Universiade in Kazan in 2013; the XXII Olympic and XI Paralympics winter games in Sochi in 2014; and some others. Currently, Russia is preparing to host the World Football Championship FIFA in 2018 and Winter Universiade in 2019 in Krasnoyarsk. Such events are organized and financed on the basis of special Federal laws at the expense of the state and in some cases municipal authorities, as well as business and 
international organizations officially supervising these events in the world.

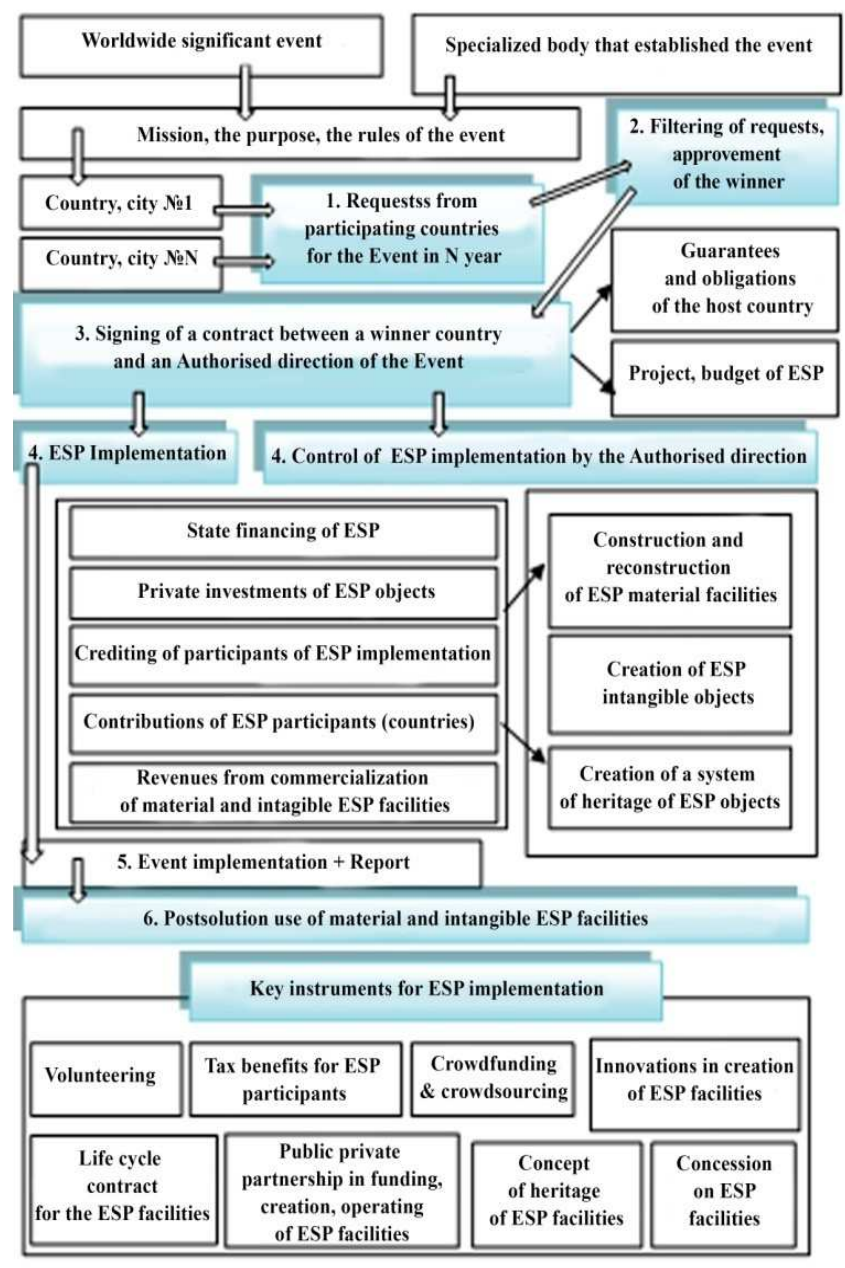

Fig. 2. General procedure and instruments of ESP implementation [3]

Typically, such activities in a particular region ensure the inflow of large financial investments in construction projects (both in existing and in the building of new ones), transport, road and other infrastructure of the region, which in the conditions of dissimilarity of the socio-economic development of our country is a very significant competitive advantage for these regions [10].

The comparative characteristic of the ESP implemented in Russia is presented in tabular style (refer to Table 2).

Thus, in order to assess the real impact of three ESPs already implemented at the beginning of 2018 in Russia on the economy of the region, the analysis of the dynamics of socioeconomic indicators at two levels was carried out: in federal districts (Primorsky Krai, the Republic of Tatarstan, Krasnodar Krai) and certain municipalities (Vladivostok, Kazan, Sochi).

Having carefully studied the indicators of socio-economic development of regions and cities before, during and after the ESP, and having compared these indicators with the development rating for territories at the Federal level, we came to an empirical conclusion - the effect of ESPs conducted in
Russia by 2018 is moderately negative. There have been no surge improvements in the social and economic development of the host territories. The declared result of our separate research is published in the monograph Ivanov V.Y., Gorshkova N.V. "The impact of event-strategic state significant mega-projects on the development of territories".

TABLE II. COMPARATIVE ANALYSIS OF ESP, IMPLEMENTED IN RUSSIA BEFORE 2018 [10]

\begin{tabular}{|c|c|c|c|c|}
\hline \multicolumn{2}{|c|}{$\begin{array}{c}\text { ESP } \\
\text { Mega-project }\end{array}$} & 1. APEC Summit & 2. Universiade & $\begin{array}{l}\text { 3. XXII Olympic } \\
\text { Games and XI } \\
\text { Paralympics } \\
\text { winter games }\end{array}$ \\
\hline \multicolumn{2}{|c|}{ Year of conduction } & 2012 & 2013 & 2014 \\
\hline \multicolumn{2}{|c|}{ City of conduction } & Vladivostok & Kazan & Sochi \\
\hline \multicolumn{2}{|c|}{ Region of conduction } & Primorski Krai & $\begin{array}{l}\text { Republic of } \\
\text { Tatarstan }\end{array}$ & Krasnodar Krai \\
\hline \multicolumn{2}{|c|}{ Federal District } & DVFO & PFO & YFO \\
\hline \multirow{2}{*}{$\begin{array}{c}\text { Cost of the } \\
\text { object }\end{array}$} & RUB bn & $690^{117}$ & 228 & 214 \\
\hline & $\begin{array}{l}\text { billion US } \\
\text { dollars }\end{array}$ & 22 & $5-6$ & 6,4 \\
\hline \multicolumn{2}{|c|}{$\begin{array}{l}\text { Increase in costs compared } \\
\text { to initially planned volume, } \\
\text { times }\end{array}$} & $\mathrm{n} / \mathrm{a}$ & $4,8-7,3$ & 4,2 \\
\hline \multicolumn{2}{|c|}{$\begin{array}{c}\text { Share of budgetary funds, } \\
\%\end{array}$} & 35 & 70 & 20 \\
\hline \multicolumn{2}{|c|}{ Total build objects, pcs } & 96 & 49 & 15 \\
\hline \multirow{2}{*}{$\begin{array}{l}\text { Inflow of } \\
\text { investments, } \\
\text { or economic } \\
\text { feasibility }\end{array}$} & $\begin{array}{c}\text { billion US } \\
\text { dollars }\end{array}$ & $\mathrm{n} / \mathrm{a}$ & $\mathrm{n} / \mathrm{a}$ & 1,3 \\
\hline & RUB bn & $\mathrm{n} / \mathrm{a}$ & 11 & $\mathrm{n} / \mathrm{a}$ \\
\hline \multicolumn{2}{|c|}{ Innovation instruments } & yes & yes & yes \\
\hline \multicolumn{2}{|c|}{ Volunteering } & yes & yes & yes \\
\hline \multicolumn{2}{|c|}{ Crowdsourcing } & no & yes & yes \\
\hline \multicolumn{2}{|c|}{$\begin{array}{l}\text { Withdrawal of land } \\
\text { for federal needs }\end{array}$} & yes & $\mathrm{n} / \mathrm{a}$ & yes \\
\hline \multicolumn{2}{|c|}{ Pre-event use } & no & $\begin{array}{c}\text { yes } \\
2011-2012 \\
\text { about } 20 \\
\text { international } \\
\text { sporting } \\
\text { competition were } \\
\text { held }\end{array}$ & no \\
\hline \multicolumn{2}{|c|}{ Post-event use } & $\begin{array}{l}\text { WEF } 2015 \\
\text { WEF } 2016\end{array}$ & $\begin{array}{c}\text { - transfer of } 18 \\
\text { sport objects out } \\
\text { of } 30 \text { to } \\
\text { universities } \\
\text { - development of } \\
\text { domestic tourism }\end{array}$ & $\begin{array}{l}\text { development of } \\
\text { domestic tourism }\end{array}$ \\
\hline
\end{tabular}

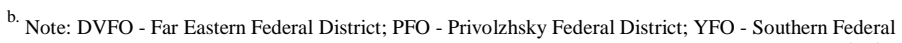
District

It should be noted that some other experts give a similar assessment. So, S\&P, assessing the overall economic effect of such major sporting events around the world (not only in Russia), asserts that this effect is moderately negative in many cases [11].

In many countries where the similar ESPs were implemented the organizers were faced with cost overrun compared to the initial budgets, with inefficient spending, with the need to use budget funds for maintaining major sports infrastructure after the event. The Russian Federation has not become the exception.

\section{Infrastructure mega-projects of Russia}

A distinctive feature of infrastructure mega-projects (further - IMP) is their priority focus on the development of infrastructure in the region and the whole country, together with their high cost. IMPs often develop the transport infrastructure of the region: strategically important points for transport junction are built - modern airports (for example, the 
expansion of the airport "Sheremetyevo" in Moscow and the construction of the airport "Yuzhny" in Rostov-on-don), highways (traffic: a road and a bridge over the Kerch Strait; sea: IMP "Northern sea route"), infrastructure associated with ensuring the efficient transportation of raw materials, gas, oil, energy (International energy project "Energy super-circle").

It is estimated that over the past five years 325 infrastructure projects of different levels of financing are at different stages of implementation in Russia [12] (refer to Table 3). More than half of the projects reviewed are in the implementation phase, in fact most are postponed and the degree of their implementation has not been confirmed. Basically, there are no clear project implementation schedules of planned projects.

TABLE III. THE STATED INFRASTRUCTURE PROJECTS [12]

\begin{tabular}{|l|c|c|}
\hline \multicolumn{1}{|c|}{ Project status } & $\begin{array}{c}\text { Number of } \\
\text { projects }\end{array}$ & $\begin{array}{c}\text { Planned amount of investment, } \\
\text { billion US dollars }\end{array}$ \\
\hline Completed & 59 & 31,8 \\
\hline $\begin{array}{l}\text { Under } \\
\text { implementation }\end{array}$ & 189 & 329,5 \\
\hline Is planned & 102 & 608,1 \\
\hline
\end{tabular}

\section{E. Epoch-making mega-projects: the experience of Russia and the world}

ESPs and IMPs are crucial for regional development of the territories of their implementation. A special kind of megaprojects can be distinguished among them, whose implementation is of epochal importance for the whole country, not only for the region.

Such epoch-making mega-projects (both ESPs and IMPs) make such significant changes in the region's economy that it becomes a turning point for its development (further - EMP). EMPs have already taken place in the past of our country and the world:

- In the USSR, construction of main Trans-Siberian railway and Baikal-Amur Mainline (BAM, 18 RUB bn [13] or, adjusted for inflation, 20 billion US dollars [7]);

- In modern Russia - Industrial Ural - Polar Ural (20052020, 850 RUB bn), Integrated development of the Lower Angara region (2006-2015, 273 RUB bn), Integrated development of the South Yakutia (20082027, 420 RUB bn) [4];

- In USA - mega-projects, implemented in a certain area by particular specialized bodies - in the Tennessee river area by the Tennessee Valley Authority, TVA [14], in the Appalachian mountains by the Appalachian Regional Commission ARC [15] and others;

- In Great Britain and France - joint mega-project: construction of tunnel under the English Channel in 1994;
- in Denmark - Europe, the mega-project Great Belt in 1997

- in Sweden - Denmark, international mega-project "The Oresund bridge" in 2000;

- others.

\section{CONCLUSION}

In response to the world economic space globalization, ESPs, IMPs and EMPs are becoming important tools for improving competitiveness of territories - host cities and regions.

The analysis of ESPs at the level of the whole country revealed their low socio-economic efficiency both in Russia and in the world. However, for the regions themselves, large financial injections, construction and reconstruction of road, transport, housing, cultural and entertainment infrastructure for the short term are becoming a source of economic growth [16]. Prolongation of the effect largely depends on the forethought degree and demand of the constructed objects.

Analysis of IMPs showed that they are effective in case of close cooperation between the national government, society and business; provided always that they are in compliance with environmental regulations.

Using the "criterion of epochality" for the purpose of selection and implementation of ESPs and IMPs allows us to talk about the strategic purpose of mega-project, about its role in the economy of the future, and more importantly - about its ability to transfer the intention of successful regional development of the territory to the regions interconnected with it, and on the long term horizon provides a breakthrough in the socio-economic development of the country.

Elaboration of methodology for the development, preparation, implementation and evaluation of ESPs, IMPs, and EMPs are relevant areas of both domestic and foreign theory and practice of mega-projects management.

\section{References}

[1] Mitrofanova, I.V. Influence of uncertainty factor on the development and implementation of modern Russian mega-projects / I.V. Mitrofanova, A.B. Tlisov, A.N. Zhukov, L.M. Shavtikova // Bulletin of Volgograd State Univercity. Series 3. Economy. Ecology -2016. -№ 3(36) - P. 107-119

[2] Mitrofanova Inna V., Russkova Elena G., Batmanova Victoria V., Shkarupa Ekaterina A. Drivers of the Regional Economic Growth and the Problem of "White Elephants" of the Russian Olympic Megaproject "Sochi 2014"// Mediterranean Journal of Social Sciences. Vol. 6, no. 4, Supplement 2, July 2015. P. 267-277 (Scopus Database). Doi: 10.5901/mjss.2015.v6n4s2p

[3] Ivanov, V.Y., Gorshkova N.V. The impact of event-strategic statesignificant mega-projects on the development of territories: joint monogr. under the general editorship of Dr.sc.oec N.V. Gorshkova; Federal state autonom. educ. institution of higher profes. education «Volgograd State Univercity». - Volgograd: VolSU Publish. house, 2017. -247 p.

[4] Kekeleva, S.V. Mega-project as an instrument of innovative approach implementation in social and economic development of Russia / S.V. Kekeleva // Social and humanitarian knowledge. - 2016. - Vol. 2. - № 3. - P. 178-186. 
[5] Voloshina, A.Y. Implementation of mega-projects as a factor of accelerated regional development / A.Y. Voloshina // Bulletin of Volgograd State Univercity. Series 3. Economy. Ecology. - 2010. - № 2. - P. 15-20.

[6] Inshakov, O.V. The potential of the evolutionary approach in strategic management of meso-territorial systems / O. V. Inshakov // Regional economics. The South of Russia. - 2011. - № 12. - P. 111-126.

[7] Mitrofanova, I.V. Mega-projects on territorial development: the experience of the United States and the Russian Federation / I.V. Mitrofanova, A.N. Zhukov, V.V. Batmanova, I.A. Mitrofanova // National interests: priorities and safety.- 2014. - №31 (268). - P. 28- 40.

[8] Aksyanov, A.S. Sport as a manipulator of international policy decisions / A.S. Aksyanov, S.I. Grachev // Global scientific potential. -2015. - №6 (51). - P. 120

[9] Baumann, R., Matheson V. Infrastructure investments and megasporting events: a comparison of the experiences of developing and developed countries // Mega-sporting events and territorial development (the works of forein authors): [scientif. publication] / originated and translated from Eng. by Dr.sc.oec, prof. M.A. Kotlyarov; [foreword of L.A. Rapoport]. — Ekaterinburg : АМБ, 2015. - Part one. - P.16.

[10] Ivanov, V.Y. The role and place of state mega-objects of event-strategic purpose in the balance of territorial development of the Russian
Federation / V.Y. Ivanov, N.V. Gorshkova // Bulletin of Volgograd State Univercity. Series 3. Economy. Ecology. - 2016. -№ 4 (37). - P.104114.

[11] Official website of the analytical Agency Standard \& Poor's. - URL: http://www.standardandpoors.com

[12] Routing - 2030: the study of infrastructure development in Russia. Official website of the Russian Direct Investment Fund. URL: http://ru.investinrussia.com/about

[13] Bykov, P. This didn't happen for a long time / P. Bykov // Expert. 2014. - №7. - P. 14-17.

[14] Tennessee Valley Authority. About TVA [Electronic source]. - URL: https://www.tva.gov/About-TVA

[15] Appalachian Regional Commission. About ARC [Electronic source]. URL: https://www.arc.gov/about/index.asp

[16] Plotnikov, V. G. Fedotova, E. G. Popkov, A. A. Castorina Harmonization of Strategic Planning Indicators of Territories' Socioeconomic Growth // Regional and Sectoral Economic Studies. 2015. - Vol. 15-2 (July-December). - P. 105-114 